\title{
Study of Confinement Index of High-Strength Concrete Columns Reinforced with High-Strength Steel Bars
}

\author{
Agustiar $^{1,2^{*}}$, Tavio ${ }^{1}$, and I Gusti Putu Raka ${ }^{1}$ \\ ${ }^{I}$ Department of Civil Engineering, Institut Teknologi Sepuluh Nopember (ITS), Surabaya, Indonesia \\ ${ }^{2}$ Department of Civil Engineering, Muhammadiyah University, Banda Aceh, Indonesia \\ *Corresponding author: ampenan70@gmail.com
}

\begin{abstract}
Nowadays, the need of mega structures such high-rise buildings and long-span bridges due to the rapid growth of population is becoming increasingly urgent. The bigger the structures the higher the load should be carried by their structural members. To resist higher load, it normally requires larger size members. In reinforced concrete members, the capacity enhancement can be attained by either increasing the element size, the grade of materials used (concrete and steel bars), or the number or size of the steel bars used. However, higher-strength materials such as concrete and steel typically have more brittle properties. To improve the ductility of the concrete, it can be achieved by providing confining steel through transverse reinforcement. For higher-strength steel bars, a chemical based research has been conducted in recent years to come up with the high strength yet ductile steel material. This paper focuses on the analysis of various strengths of concrete columns $30 \mathrm{MPa}$ and to $60 \mathrm{MPa}$ reinforced and confined with high-strength reinforcing steel bars $550 \mathrm{MPa}$ (Grade 80) with variety cross section of columns. From the study, it can be concluded that the confinement index decreases significantly with the increase of concrete strength. The use of higher-strength transverse steel increases the confinement index. The greater strengths of concrete used, the confinement ratio will be smaller at the same spacing.
\end{abstract}

Keywords - concrete columns, confinement index, high strength concrete, high strength steel, transverse steel.

\section{INTRODUCTION}

$\mathrm{T}_{\mathrm{b}}$ he need of mega structures such as high-rise buildings and long-span bridges due to the rapid growth of population is urgent. This is due to economic needs, limited land and higher land prices. In Indonesia until 2017 the high level building is Gama Tower with a height of 285.5 meters. In the year 2022 high buildings in Indonesia is planned signature Tower Jakarta with a height of 638 meters. The world's tallest building is located in Dubai, United Arab Emirates with a height of 828 meters (CTBUH). Based on data from CTBUH, the percentage of use of construction materials used in the world's top 100 high-rise buildings is based on two different years [1], shown in Figure 1.

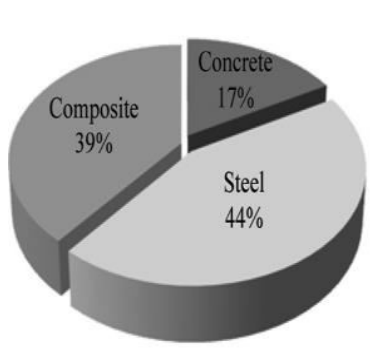

(a) 2000

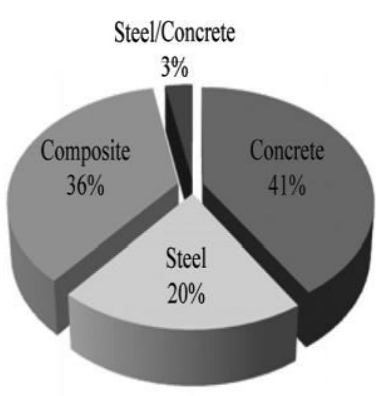

(b) 2011
Figure 1. Percentage of material use in high-rise buildings
From Figure 1, it shows that the use of concrete and material composites is increasing. the needs of high-level buildings required materials with high strength. Materials commonly used for high-rise buildings are reinforced concrete. Concrete strong receives compressive forces and steel receives tensile strength, so this material is a suitable combination as a composite material. To improve the performance of reinforced concrete is given confinement.

The most important design consideration for ductility in plastic hinge regions of reinforced concrete columns is the provision of sufficient transverse reinforcement in the form of spirals or circular hoops or of rectangular arrangements of steel, in order to confine the compressed concrete, to prevent buckling of the longitudinal bars, and to prevent shear failure. Tests have shown that the confinement of concrete by suitable arrangements of transverse reinforcement results in a significant increase in both the strength and the ductility of compressed concrete [2].

\section{BEHAVIOR OF COLUMNS}

Columns are defined as member that carry loads chiefly in compression. The behavior of reinforced concrete compression members is dominated by concrete which tends to be brittle unless confined by properly designed transverse reinforcement. In seismic resistant columns, where inelastic response is expected, sufficient ductility must be ensured through the confinement of core concrete. This can be achieved by using spiral 
reinforcement or closely spaced hoops, overlapping hoops, and crossties. The increased inelastic deformability is assumed to be met if the column core is confined sufficiently to maintain column concentric load capacity beyond the spalling of cover concrete. Concrete is strong in compression but brittle in nature.

The stress -strain relationship of concrete is that the stress is initially parabolic and reduces linearly to zero. Typical stress-strain relationship of concrete is shown in Figure 2. the strain coresponding to the maximum stress is about 0,002. Slope od decending branch depends on the cylinder strength of concrete and become steeper wen concrete strength increases.

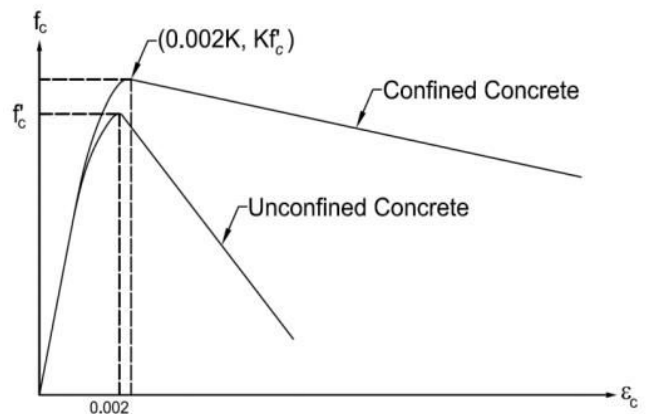

Figure 2. Typical stress-strain relationship of concrete [3]

\section{A. Capacity of reinforced concrete column}

The collapse behavior of structural elements of reinforced concrete columns depends on the eccentricity of the working axial load. In axial centric loading the column only experiences a compressive force. While the axial load conditions occur eccentricity then the column has axial style and also bending. This causes the model of collapse of reinforced concrete depending on the condition of the dominant force of force or tensile force. The model of reinforced concrete collapse illustrated by the strain distribution relationship, shown in Figure 3.

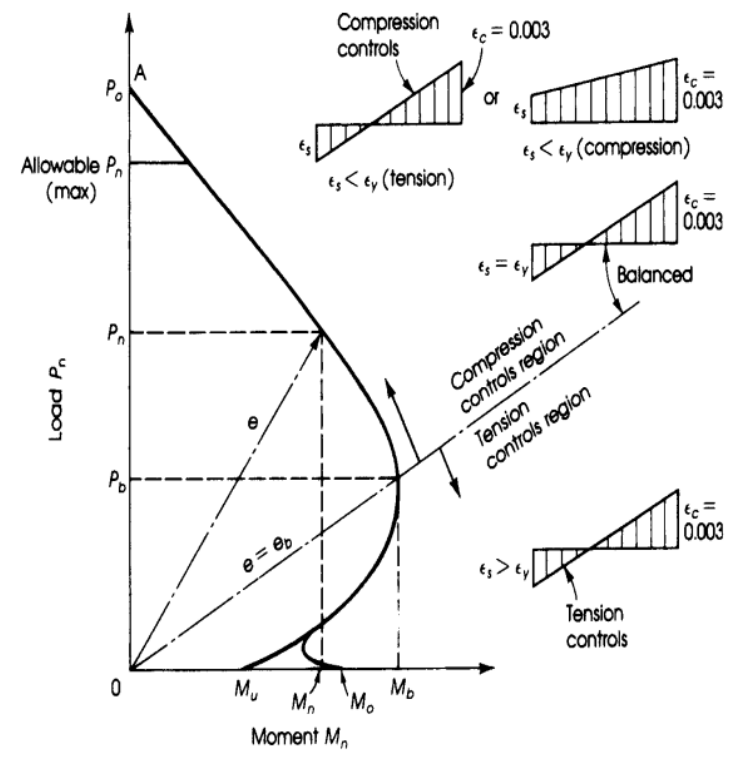

Figure 3. Relationship of strain distribution on the interaction diagram [4]

In general, the higher the axial compressive load on the column, the greater the amount of confining reinforcement necessary to achieve ductile performance. This is because a high axial load means a large neutral axis depth, which in turn means that the flexural capacity of the column is more dependent on the contribution of the concrete compressive stress distribution.

The capacity of short reinforced concrete columns due to axial loads employed can be determined by equation 1 .

$P_{n}=0,85 f_{c}^{\prime}\left(A_{g}-A_{s t}\right)+f_{y} A_{s t}$

The value of $0,85 f_{c}^{\prime}\left(A_{g}-A_{s t}\right)$ is the contribution of the concrete in accepting the load and $f_{y} A_{s t}$ is the contribution of the reinforcement in accepting the load.

The behavior of reinforced concrete compression members is dominated by concrete which tends to be brittle unless confined by properly designed transverse reinforcement. The increased inelastic deformability is assumed to be met if the column core is confined sufficiently to maintain column concentric load capacity beyond the spalling of cover concrete. This performance criterion results in the following minimum confinement reinforcement as stated in Sec.18.7.5.4 of ACI318R-14. Transverse reinforcement for columns of special moment frames shows Table 1 .

Table 1. Transverse reinforcement for columns of special moment frames [5]

\begin{tabular}{|c|c|c|c|}
\hline $\begin{array}{l}\text { Penulangan } \\
\text { Transversal }\end{array}$ & kondisi & \multicolumn{2}{|r|}{ penggunaan } \\
\hline \multirow[t]{2}{*}{$\begin{array}{l}A_{s h} / s b_{c} \\
\text { for } \\
\text { rictilinear } \\
\text { hoop }\end{array}$} & $\begin{array}{l}P_{u} \leq 0,3 \\
A_{g} f^{\prime}{ }_{c} \text { and } \\
f_{c}^{\prime} \leq 70 \\
\mathrm{MPa}\end{array}$ & $\begin{array}{l}\text { Greater } \\
\text { of (a) } \\
\text { and (b) }\end{array}$ & \multirow{2}{*}{$\begin{array}{ll}0,3 \frac{f_{c}^{\prime}}{f_{y t}}\left[\left(\frac{A_{g}}{A_{c h}}\right)-1\right] & \text { (a) } \\
0,09 \frac{f_{c}^{\prime}}{f_{y t}} & \text { (b) } \\
0,2 k_{f} k_{n} \frac{P_{u}}{f_{y t} A_{c h}} & \text { (c) }\end{array}$} \\
\hline & $\begin{array}{l}P_{u}>0,3 \\
A_{g} f^{\prime}{ }_{c} \text { or } \\
f^{\prime}{ }_{c}>70 \\
\mathrm{MPa}\end{array}$ & $\begin{array}{l}\text { Greater } \\
\text { of (a), } \\
\text { (b) and } \\
\text { (c) }\end{array}$ & \\
\hline \multirow[t]{2}{*}{$\begin{array}{l}A_{s h} / s b_{c} \\
\text { for spiral } \\
\text { or } \\
\text { Circular } \\
\text { hoop }\end{array}$} & $\begin{array}{l}P_{u} \leq 0,3 \\
A_{g} f^{\prime}{ }_{c} \text { and } \\
f_{c}^{\prime} \leq 70 \\
\mathrm{MPa}\end{array}$ & $\begin{array}{l}\text { Greater } \\
\text { of (d) } \\
\text { and (e) }\end{array}$ & \multirow{2}{*}{$\begin{array}{l}0,45 \frac{f_{c}^{\prime}}{f_{y t}}\left[\left(\frac{A_{g}}{A_{c h}}\right)-1\right](\mathrm{d}) \\
0,12 \frac{f_{c}^{\prime}}{f_{y t}} \\
0,35 k_{f} \frac{P_{u}}{f_{y t} A_{c h}}\end{array}$} \\
\hline & $\begin{array}{l}P_{u}>0,3 \\
A_{g} f_{c}{ }_{c} \text { or } \\
f_{c}^{\prime}>70 \\
\mathrm{MPa}\end{array}$ & $\begin{array}{l}\text { Greater } \\
\text { of (d), } \\
\text { (e) and } \\
\text { (f) }\end{array}$ & \\
\hline
\end{tabular}

\section{B. Concrete confinement}

Transverse reinforcement are specified in design codes for beams and columns to serve the following four functions: (a) to prevent buckling of longitudinal reinforcing bars, (b) to resist shear forces and to avoid shear failure, (c) to confine the concrete core to provide sufficient deformability (ductility), (d) to clamp together lap splices-after splitting cracks form parallel to the splices, ties or spirals restrain slip between the spliced bars. Note that none of these functions are effective till the concrete cracks or spalls; All are critical for the column to maintain vertical or lateral capacitie sunder earthquake displacements in the post-yield range [6].

The capacity of the column in accepting the load and deformation can be increased by providing confinement. Results of previous different investigators, have carried out numerous tests on nearly full-size specimens and have demonstrated that confinement is improved if (1) 


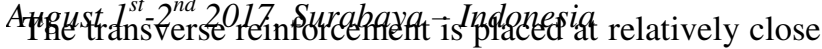
spacing; (2) additional supplementary overlapping hoops or cross ties with several legs crossing the section are included; (3) the longitudinal bars are well distributed around the perimeter; (4) the volume of transverse reinforcement to the volume of the concrete core or the yield strength of the transverse reinforcement is increased; and (5) spirals or circular hoops are used instead of rectangular hoops and supplementary cross ties [7-27]

An approach similar to the one used by Sheikh and Uzumeri (1980), is adopted to determine the effective lateral confining pressure on the concrete section[2]. The maximum transverse pressure from the confining steel can only be exerted effectively on that part of the concrete core where the confining stress has fully developed due to arching action. Figure 4 and 5 show the arching action that is assumed to occur between the levels of transverse circular and rectangular hoop reinforcement. Midway between the levels of the transverse reinforcement, the area of ineffectively confined concrete will be largest and the area of effectively confined concrete core $A e$ will be smallest.

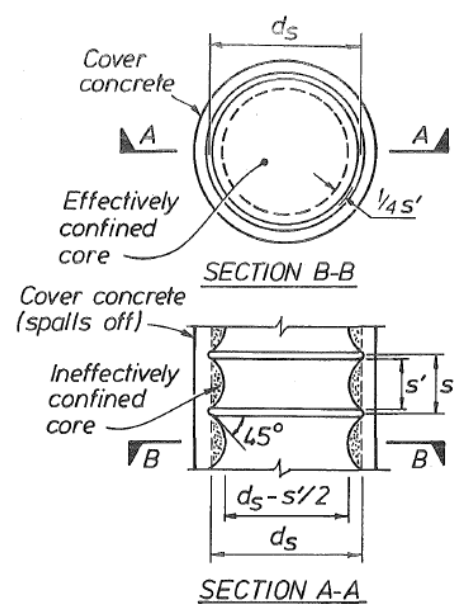

Figure 4. Effectively Confined Core for Circular Hoop Reinforcement [2]

Figure 5. Effectively Confined Core for Rectangular Hoop Reinforcement [2]

Assumed that confinement effectiveness lateral is[2]:

$f^{\prime}{ }_{l}=K_{e} f_{l}$

Where $f_{l}=$ lateral pressure from the transverse reinforcement, assumed to be uniformly distributed over the surface of the concrete core.

$k_{e}=\frac{A_{e}}{A_{c c}}$

$k_{e}=$ confinement effectiveness coefficient

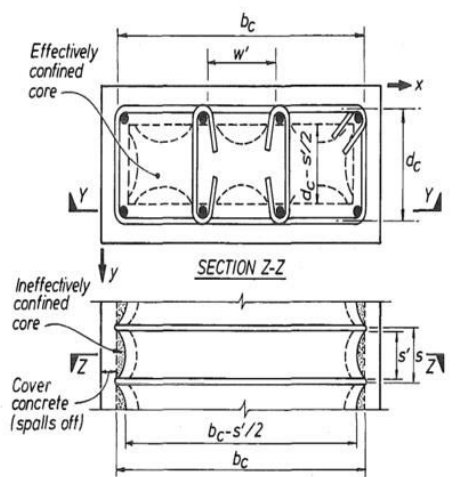

$A_{e}=$ area of effectively confined concrete core

$A_{c c}=A_{c}\left(1-\rho_{c c}\right)$

$\rho_{c c}=$ ratio of area of longitudinal reinforcement to area of core of section

$A_{c c}=$ area of core of section enclosed by the center lines of the perimeter spiral or hoop

In Fig. 3, the arching action is again assumed to act in the form of second-degree parabolas with an initial tangent slope of $45^{\circ}$. Arching occurs vertically between layers of transverse hoop bars and horizontally between longitudinal bars. For one parabola, the ineffectual area is

$\frac{\left(w_{i}^{\prime}\right)^{2}}{6}$. Thus the total plan area of ineffectually confined core concrete at the level of the hoops when there are $n$ longitudinal bars is :

$$
A_{i}=\sum_{i=1}^{n} \frac{\left(w_{i}^{\prime}\right)^{2}}{6}
$$

Incorporating the influence of the ineffective areas in the elevation (Fig. 4), the area of effectively confined concrete core at midway between the levels of transverse hoop reinforcement is:

$$
A_{e}=\left(b_{c} d_{c}-\sum_{i=1}^{n} \frac{\left(w_{i}^{\prime}\right)^{2}}{6}\right)\left(1-\frac{s^{\prime}}{2 b_{c}}\right)\left(1-\frac{s^{\prime}}{2 d_{c}}\right)
$$

where $b_{c}$ and $d_{c}=$ core dimensions to centerlines of perimeter hoop in $x$ and $y$ directions, respectively, where $b_{c}>d c . w_{i}^{\prime}$ is the /th clear distance between adjacent longitudinal bars. Hence from Eq. 3 the confinement effectiveness coefficient is for rectangular hoops is:

$$
K_{e}=\frac{\left(1-\sum_{i=1}^{n} \frac{\left(w_{i}^{\prime}\right)^{2}}{6 c_{x} c_{y}}\right)\left(1-\frac{s^{\prime}}{2 c_{x}}\right)\left(1-\frac{s^{\prime}}{2 c_{y}}\right)}{\left(1-\rho_{c c}\right)}
$$

\section{METHOD}

Used two variations of the quality of concrete that is 30 $\mathrm{MPa}$ and $60 \mathrm{MPa}$. The cross section of the specimen columns is square with dimensions of $150 \mathrm{~mm}$ up to 350 $\mathrm{mm}$. The quality of reinforcement used is fyh $=550 \mathrm{MPa}$ for horizontal reinforcement and fyl $=550$ for longitudinal reinforcement. This analysis is aimed to determine the effect of concrete quality as well as the variation of rectangular cross-section dimension of reinforced concrete against confinement. The confinement spacing used is $50 \mathrm{~mm}$ until $150 \mathrm{~mm}$.

\section{RESULTS AND DISCUSSION}

Based on the result of data analysis using variation of concrete quality, cross section and spacing of stirrup, hence can some result as follows:

\section{A. The influence of spacing stirrup and column cross} section 
Based on the result analysis of spacing stirrup and column cross section analysis shown that the confinement ratio increases at the same cross-sectional dimension. The example is shown of $150 \mathrm{~cm}$ square cross section. The spacing of the stirrups is getting smaller from $150 \mathrm{~cm}$ to $50 \mathrm{~cm}$, the confinement ratio is increasing from 1.2 to 2.68 , shown in Table 2. The results of the confinement index of the analysis variation spacing stirrup and the cross-sectional dimension at The quality of $30 \mathrm{MPa}$ concrete is shown in Table 2 and Figure 6.

Table 2. Spacing stirrups and cross-sectional dimensions to the confinement ratio on the concrete strength $30 \mathrm{MPa}$

\begin{tabular}{cccccc}
\hline 150 & 1,20 & 1,26 & 1,24 & 1,22 & 1,19 \\
\hline 120 & 1,42 & 1,41 & 1,35 & 1,30 & 1,26 \\
\hline 100 & 1,65 & 1,56 & 1,46 & 1,39 & 1,33 \\
\hline 75 & 2,06 & 1,83 & 1,66 & 1,55 & 1,47 \\
\hline 50 & 2,68 & 2,27 & 2,01 & 1,83 & 1,70 \\
\hline Note: & $\begin{array}{l}\text { C= Cross section (mm) } \\
\text { S = spacing of stirrup (mm) }\end{array}$ \\
&
\end{tabular}

The value of the confinement ratio of 2.68 indicates a strength increase of 2.68 times from the initial strength of the planned concrete. So the smaller the spaced stirrup the increased force due to the greater the confinement. The curve of the relation of the confinement ratio and the cross-sectional variation is shown in Figure 6.

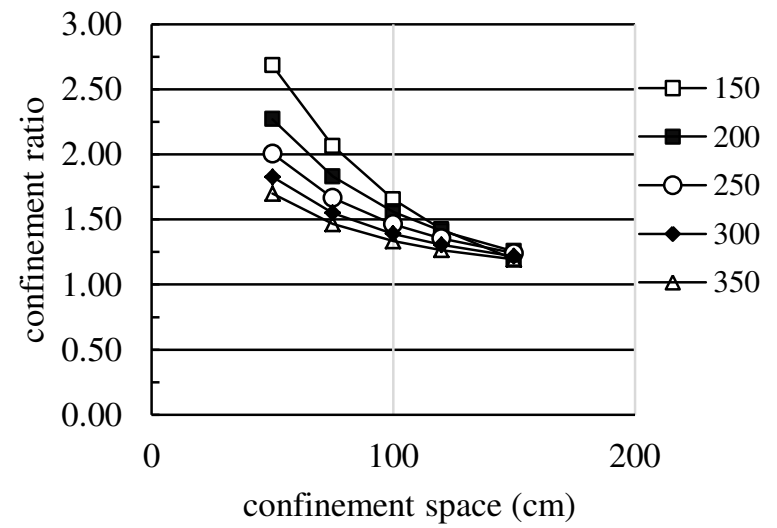

Figure 6. Curve confinement ratio and dimention of cross section at strength concrete $30 \mathrm{MPa}$

The influence of spacing of stirrup and column cross section on concrete strength of $60 \mathrm{MPa}$ shows the same trend with the concrete strength $30 \mathrm{MPa}$, that is, the smaller the spacing of the stirrup, the greater the confinement ratio at the same cross-sectional dimension. The example is shown on a $150 \mathrm{~cm}$ cross-section, wherein the cross-sectional range of $150 \mathrm{~cm}$ to 50 , the value of the confinement ratio also increases, from 1.1 to 2.07, shown in Table 3. The curve of the confinement ratio and the cross-section of the $60 \mathrm{MPa}$ concrete is shown In Figure 7.

Table 3. Spacing stirrups and cross-sectional dimensions to the confinement ratio on the concrete strength $60 \mathrm{MPa}$

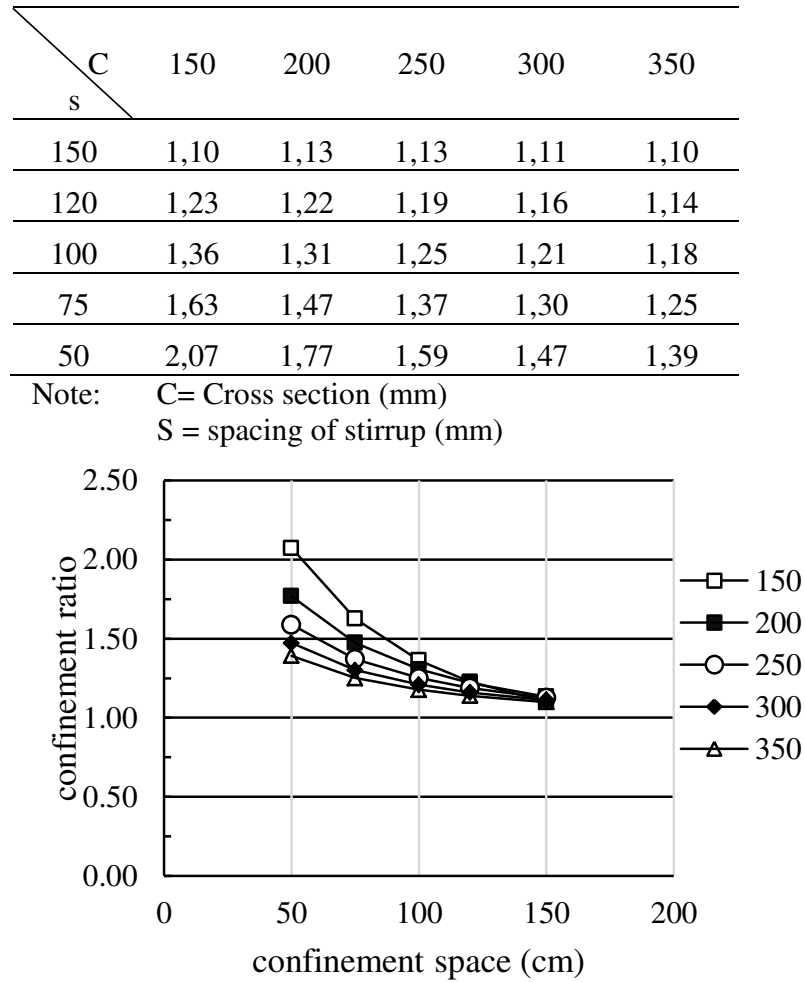

Figure 7. Curve confinement ratio and dimention of cross section at strength concrete $60 \mathrm{MPa}$

Figure 7 shown that the variation of square sectional in the same space of the stirrup. it shows that the larger the cross-sectional dimension smaller the confinement ratio. The example in the $50 \mathrm{~cm}$ spaced spacing, the cross-sectional dimension varied from $150 \mathrm{~cm}$ to 350 $\mathrm{cm}$, the value of the confinement ratio decreased from 2.68 to 1.70 shown in Table 1 , whereas in Table 2 , the value of the confinement ratio of 2.07 To 1.39. This shows the square sectional variation affecting the confinement ratio on the same spaced line, shown in Figure 8. When viewed from the decline that occurs than for the spacing of the stirrups greater than $100 \mathrm{~mm}$ more gentle compared with the spaced stirrups less than 100 $\mathrm{mm}$. This shows the effectiveness of confinement for spaces greater than $100 \mathrm{~mm}$ less effective.

\section{B. Effect of concrete strength}

The relationship of spacing, the cross-sectional dimension of the concrete quality is shown in Figure 8 . there are two lines of continuous lines and dashed lines. The continuous lines for concrete with a compressive strength of $60 \mathrm{MPa}$, while the dashed line represents the $30 \mathrm{MPa}$ concrete quality. The confinement ratio is influenced by the quality of the concrete. The greater the quality of concrete used, the confinement ratio will be smaller at the same spacing. 


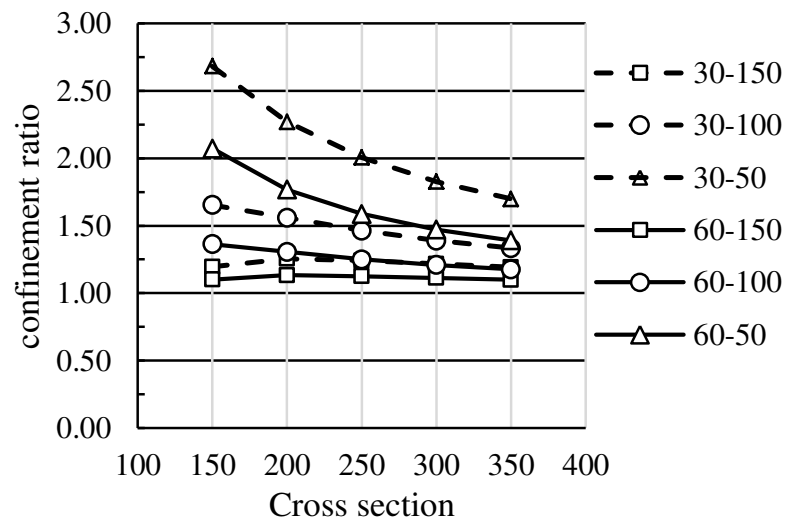

Figure 8. Curve confinement ratio and variation dimention of cross section at strength concrete $30 \mathrm{MPa}$ and $60 \mathrm{MPa}$

\section{CONCLUSION}

Based on the results of the analysis by using dimensional cross-sectional variation, concrete quality and spacing stirrup, it can be drawn some conclusions:

1. The smaller the spacing of the stirrup, the greater the confinement ratio at the same cross-sectional dimension

2. The confinement ratio is influenced by the quality of the concrete. The greater the quality of concrete used, the confinement ratio will be smaller at the same spacing.

3. The cross-sectional size affected the confinement ratio. The larger the cross-sectional dimension the confinement ratio will be small at the same spacing.

\section{REFERENCES}

[1] M. Y, Cheng., and B. M, Giduquio., Cyclic Behavior of Reinforced Concrete Flexural Members Using HighStrength Flexural Reinforcement", ACI Structural Journal, V. 111, pp 1-6, January-December 2014.

[2] J.B, Mander., M.J.N, Priestley., and R, Park,. "Theoretical stress-strain model of confined concrete." J. Struct. Eng.,114(8), pp.1804-1826, August 1988.

[3] D.C, Kent., and R, Park,. "Flexural members with confined concrete." Journal of the Structural Division, Proc. of the American Society of Civil Engineers, 97(ST7), pp. 1969-1990, 1971.

[4] M,N, Hassoun and A, Al-Manaseer., " structural concrete theory and design", 4th edition, John Wiley \& Son, 2008, pp.331-389.

[5] ACI 318-14, "Building Code Requirements for Structural Concrete (ACI 318-11) and Commentary on Building Code Requirements for Structural Concrete", 2014, Farmington Hills, MI.

[6] N.Subramanian, Design of Confinement Reinforcement for Reinforced Concrete Columns, The Indian Concrete Journal, pp. 1-9, 2011.

[7] Pudjisuryadi, P.; Tavio; and Suprobo, P., "Axial Compressive Behavior of Square Concrete Columns Externally Collared by Light Structural Steel Angle Sections," International Journal of Applied Engineering Research (IJAER), Research India Publications, V. 11, No. 7, pp. 4655-4666, 2016.

[8] Pudjisuryadi, P.; Tavio; and Suprobo, P., "Performance of Square Reinforced Concrete Columns Externally Confined by Steel Angle Collars under Combined Axial and Lateral Load," Procedia Engineering Journal, Elsevier, V. 125, pp. 1043-1049, 2015.

[9] Tavio; and Kusuma, B., "Analytical Model for Axial Stress-Strain Behavior of Welded Reinforcement Grid Confined Concrete Columns," Journal of Asian Concrete Federation, Asian Concrete Federation (ACF), V. 1, No. 1, pp. 1-10, Sept. 2015.

[10] Tavio; Pudjisuryadi, P.; and Suprobo, P., "Strength and Ductility of External Steel Collared Concrete Columns under Compressive Loading," Journal of Asian Concrete Federation, Asian Concrete Federation (ACF), V. 1, No. 1, pp. 47-56, Sept. 2015.

[11] Kusuma, B.; Tavio; and Suprobo, P., "Behavior of Concentrically Loaded Welded Wire Fabric Reinforced Concrete Columns with Varying Reinforcement Grids and Ratios," International Journal of ICT-aided Architecture and Civil Engineering (IJIACE), SERSC, 20 Virginia Court, Sandy Bay, Tasmania, Australia, V. 2, No. 1, pp. 1-15, June 2015.

[12] Pudjisuryadi, P.; Tavio; and Suprobo, P., "Analytical Confining Model of Square Reinforced Concrete Columns using External Steel Collars," International Journal of ICT-aided Architecture and Civil Engineering (IJIACE), SERSC, 20 Virginia Court, Sandy Bay, Tasmania, Australia, V. 1, No. 1, pp. 1-18, June 2014.

[13] Tavio; Kusuma, B.; and Suprobo, P., "Experimental Behavior of Concrete Columns Confined by Welded Wire Fabric as Transverse Reinforcement under Axial Compression," ACI Structural Journal, American Concrete Institute (ACI), Farmington Hills, Michigan, USA, V. 109, No. 3, pp. 339-348, May-June 2012.

[14] Kusuma, B.; Tavio; and Suprobo, P., "Axial Load Behavior of Concrete Columns with Welded Wire Fabrics as Transverse Reinforcement," Procedia Engineering Journal, Elsevier, V. 14, pp. 2039-2047, July 2011.

[15] Tavio; Suprobo, P.; and Kusuma, B., "Investigation of Stress-Strain Models for Confinement of Concrete by Welded Wire Fabric," Procedia Engineering Journal, Elsevier, V. 14, pp. 2031-2038, July 2011.

[16] Tavio; and Kusuma, B., "Stress-Strain Model for HighStrength Concrete Confined by Welded Wire Fabric," Discussion, Journal of Materials in Civil Engineering, American Society of Civil Engineers (ASCE), Reston, Virginia, USA, V. 21, No. 1, pp. 40-45, Jan. 2009.

[17] Tavio; Pudjisuryadi, P.; and Suprobo, P., "Experimental Behavior of RC Columns Externally Confined by Steel Collars Subjected to Axial Compression," Proceeding of the 6th International Conference of Asian Concrete Federation, 21-24 Sept. 2014, Asian Concrete Federation (ACF), Seoul, Korea, pp. 606-613.

[18] Tavio; and Kusuma, B., "A Model of Confinement Effect on Stress-Strain Relation of Reinforced Concrete Columns Confined with Welded Wire Fabric," Proceeding of the 6th International Conference of Asian Concrete Federation (ACF 2014), 21-24 Sept. 2014, TheK Seoul Hotel, Seoul, Korea, pp. 599-605.

[19] Tavio; Suprobo, P.; and Kusuma, B., "Strength and Ductility Enhancement of Reinforced HSC Columns Confined with High-Strength Transverse Steel," Proceeding of the Eleventh East Asia-Pacific Conference on Structural Engineering \& Construction (EASEC-11), 19-21 Nov. 2008, Taipei International Convention Center, Taipei, Taiwan, pp. 350-351.

[20] Tavio; Suprobo, P.; and Kusuma, B., "Ductility of Confined Reinforced Concrete Columns with Welded Reinforcement Grids," Proceedings of the International Conference on Concrete Construction: Excellence in Concrete Construction through Innovation, 9-10 Sept. 
2008, Kingston University, London, UK, CRC Press, Taylor \& Francis Group, A Balkema Book, pp. 339-344.

[21] Tavio; Suprobo, P.; and Kusuma, B., "Effects of Grid Configuration on the Strength and Ductility of HSC Columns Confined with Welded Wire Fabric under Axial Loading," Proceeding of the 1st International Conference on Modern, Construction and Maintenance of Structures, V. 1, 10-11 Dec. 2007, Hanoi, Vietnam, pp. 178-185.

[22] Cusson, D. and Paultre, P., " High-Strength Concrete Columns Confined By Rectangular Ties ", ASCE Journal of Structural Engineering, Vol. 120, No. 3, March, pp. 783-804, March 1994.

[23] Cusson, D. and Paultre, P., "Stress-Strain Model For Confined High-Strength Concrete", ASCE Journal of Structural Engineering, V.121, No.3, pp. 468-477, March 1995.

[24] Paultre, P., and Légeron, F., "Confinement Reinforcement Design for Reinforced Concrete Columns", ASCE, Journal of Structural Engineering, Vol. 134, No. 5, May 1, pp. 738-749, May 2008.

[25] Sakai, K., and Sheikh, S. A., "What Do We Know About Confinemet in Reinforced Concrete Columns? (Acritical Review of Previous Work and Code Provisions), ACI Structural Journal, PP 192-207, March - April 1989.

[26] Sheikh, S. A., and Uzumeri, S. M.,"Strength And Ductility Of Tied Concrete Columns." ASCE, Journal of Structural Engineering, 106(5), pp.1079-1102. October 1980.

[27] Sheikh, S. A., and Uzumeri, S. M., "Analytical model for concrete confinement in tied columns." ASCE, Journal of Structural Engineering, 108(12), pp.2703- 2722, December 1982. 